\title{
UTILISING BIOLOGICAL GEOTEXTILES: INTRODUCTION TO THE BORASSUS PROJECT AND GLOBAL PERSPECTIVES
}

\author{
M. A. FULLEN ${ }^{1 *}$, M. SUBEDI ${ }^{1}$, C. A. BOOTH ${ }^{1}$, R. W. SARSBY ${ }^{1}$, K. DAVIES ${ }^{1}$, R. BHATTACHARYYA ${ }^{1}$, R. KUGAN ${ }^{1}$, \\ D. A. LUCKHURST ${ }^{1}$, K. CHAN ${ }^{1}$, A. W. BLACK ${ }^{1}$, D. TOWNROW ${ }^{1}$, T. JAMES ${ }^{1}$, J. POESEN ${ }^{2}$, T. SMETS ${ }^{2}$, A. KERTESZ KO $^{3}$, \\ A. TOTH $^{3}$, Z. SZALAI ${ }^{3}$, G. JAKAB ${ }^{3}$, B. JANKAUSKAS ${ }^{4}$, G. JANKAUSKIENE ${ }^{4}$, C. BÜHMANN ${ }^{5}$, G. PATERSON ${ }^{5}$, \\ E. MULIBANA ${ }^{5}$, J. P. NELL ${ }^{5}$, G. M. E. VAN DER MERWE ${ }^{5}$, A. J. T. GUERRA ${ }^{6}$, J. K. S. MENDONÇA ${ }^{6}$, T. T. GUERRA ${ }^{6}$, \\ R. SATHLER ${ }^{6}$, J. F. R. BEZERRA ${ }^{6}$, S. M. PERES ${ }^{6}$, ZHENG YI $^{7}$, LI YONGMEI, TANG LI ${ }^{7}$, M. PANOMTARANICHAGUL ${ }^{8}$, \\ S. PEUKRAI ${ }^{8}$, D. C. THU ${ }^{9}$, T. H. CUONG ${ }^{9}$, T. T. TOAN ${ }^{9}$, F. JONSYN-ELLIS ${ }^{10}$, J. Z. SYLVA ${ }^{10}$, A. COLE $^{10}$, \\ B. MULHOLLAND ${ }^{11}$, M. DEARLOVE ${ }^{11}$, C. CORKILL ${ }^{12}$ AND P. TOMLINSON ${ }^{12}$ \\ ${ }^{1}$ University of Wolverhampton, Wolverhampton WV1 $1 L Y$, UK \\ ${ }^{2}$ Catholic University of Leuven, B-3000 Leuven, Belgium \\ ${ }^{3}$ Geographical Research Institute, Budapest H-1112, Hungary \\ ${ }^{4}$ Kaltinenai Research Station of the Lithuanian Institute of Agriculture, LT-5926, Lithuania \\ ${ }^{5}$ Agricultural Research Council, Pretoria, South Africa \\ ${ }^{6}$ Federal University of Rio de Janeiro, 21940-590 Rio de Janeiro, Brazil \\ ${ }^{7}$ Yunnan Agricultural University, Kunming 650201, PR China \\ ${ }^{8}$ Chiang Mai University, 50200 Chiang Mai, Thailand \\ ${ }^{9}$ Hanoi Agricultural University, Hanoi, Vietnam \\ ${ }^{10}$ The Catholic Development Organization (CaDO), The Gambia \\ ${ }^{11}$ Duchy Agricultural College, Camborne, UK \\ ${ }^{12}$ Centre for Manx Studies, The University of Liverpool, Douglas, Isle of Man, UK
}

Received 7 February 2011; Accepted 7 February 2011

\begin{abstract}
Field and laboratory studies indicate that utilisation of biological geotextiles constructed from palm-leaves and other selected organic materials are an effective, sustainable and economically viable soil conservation technique. The three-year plus (1 July $2005-28$ February 2009) EU-funded BORASSUS Project (contract no. INCO-CT-2005-510745) evaluated the long-term effectiveness of biological geotextiles in controlling soil erosion and assessing their sustainability and economic viability. These studies progressed in ten countries, both in the 'industrial north' (in Europe) and in the 'developing south' (Africa, South America and South East Asia). The studied countries in the 'developing south' included Brazil, China, The Gambia, South Africa, Thailand and Vietnam. The 'industrial north' countries included Belgium, Hungary, Lithuania and the UK. The main findings of these studies are summarised in this paper and thematic information is presented in the other four papers in this Special Issue.

Biological geotextiles offer potentially novel bioengineering solutions to environmental problems, including technologies for soil conservation, sustainable plant production and use of indigenous plants, improved ecosystem management by decreasing deforestation, improving agroforestry and cost-effective biogeotextile applications in diverse environments. Biogeotextiles may provide socio-economic platforms for sustainable development and the benefits for developing countries may include poverty alleviation, engagement of local people as stakeholders, employment for disadvantaged groups, small and medium enterprise (SME) development, earning hard currency, environmental education and local community involvement in land reclamation and environmental education programmes. These benefits are achieved through: (i) promotion of sustainable and environmentally friendly palm-agriculture to discourage deforestation, promoting both reforestation and agroforestry; (ii) construction of biogeotextiles enabling development of a rural labour-intensive industry, particularly encouraging employment of socially disadvantaged groups and (iii) export of biogeotextiles to industrialised countries could earn hard currency for developing economies, based on the principles of fair trade. Research and development activities of the BORASSUS Project have improved our knowledge on the effect of biogeotextile mats on the micro- and macro-soil environments and at larger scales through controlled laboratory and field experiments in diverse environments. Copyright (C) 2011 John Wiley \& Sons, Ltd.
\end{abstract}

KEY WORDS: $\quad$ soil and water conservation; bioengineering technology; socio-economic development; BORASSUS; biological geotextiles

* Correspondence to: M. A. Fullen, University of Wolverhampton, Wolverhampton WV1 1LY, UK.

E-mail: m.fullen@wlv.ac.uk 


\section{INTRODUCTION}

Recent improvements have been made in soil conservation technology and over the last three decades significant advances have been made in our understanding of soil erosion mechanisms and rates under different environmental conditions. However, there have been relatively few advances in developing innovative soil conservation techniques. Moreover, comparatively little research has been conducted at the interface between soil technology and socio-economic issues in developing countries, such as sustainable development, poverty alleviation and rural employment. One technique for soil conservation is the use of biological geotextiles (biogeotextiles), which can create stable, non-eroding environments that provide the time necessary for vegetation to establish and grow. If constructed from indigenous materials, biogeotextiles can be effective, affordable and compatible with sustainable land management strategies (Booth et al., 2005).

Despite synthetic geotextiles dominating the commercial market, geotextiles constructed from organic materials are highly effective in erosion control (Davies et al., 2006) and vegetation establishment (Rickson, 2000). Furthermore, they usually have 100 per cent biodegradability and better adherence to the soil. Moreover, in developing regions, commercially marketed materials are usually too expensive. Thus, the BORASSUS Project assessed the feasibility of employing palm-leaf geotextile mats and other selected biomats, such as maize (Zea mays L.) stalk mats, rice (Oryza sativa L.) straw mats and bamboo (Bambusa bambos L.) mats, as potential soil conservation techniques. This approach involves the promotion of sustainable and environmentally friendly palm-agriculture and offers a potentially profitable technique to augment the income of financially deprived farmers. This Special Issue summarises the aims and objectives of the BORASSUS Project and presents the main findings regarding the potential contribution of biogeotextiles to sustainable development.

\section{THE BORASSUS PROJECT}

Biological geotextiles can potentially advance soil erosion control in complex environmental situations, for instance on building and road construction sites, in gully stabilisation and reclamation projects and in coastal defence (Jankauskas et al., 2010). However, as yet studies do not allow quantification of the effectiveness of biogeotextiles in decreasing soil erosion rates by wind or water. Several workpackages in this project addressed this issue through field measurements. However, a particular field site does not always offer the range of environmental conditions that can be found elsewhere in the region. One approach to establish the effectiveness of biogeotextiles for such conditions is through controlled laboratory experiments, during which erosive processes (rainfall, runoff and wind) are simulated for representative soil and slope conditions in the absence of, and with, biogeotextiles. Laboratory simulation studies were completed in Belgium, China and South Africa, to validate field measurements in laboratory situations.

Biological geotextiles offer considerable potential to contribute to sustainable development and soil conservation. They efficiently and economically conserve soil, and evidence is presented in this Special Issue that in developing countries, their use can promote sustainable and environmentally friendly agriculture and labour-intensive employment.

The European Commission funded the BORASSUS Project (contract number INCO-CT-2005-510745) for over 3-years (2005-2009) to investigate 'The Environmental and Socio-economic Contribution of Palm Geotextiles to Sustainable Development and Soil Conservation' (Booth et al., 2007). The BORASSUS team scientifically tested the following four hypotheses:

(1) Promotion of sustainable and environmentally friendly palm-agriculture would discourage deforestation and promote both reforestation and agroforestry. It would also offer a potentially profitable technique, which would provide financially deprived farmers with supplementary income from palm-geotextiles and thus contribute to poverty alleviation.

(2) Construction of palm-geotextiles would develop into a rural based labour-intensive industry, particularly encouraging the employment of socially disadvantaged groups, such as women, disabled and elderly people. This would in turn contribute to the stabilisation of rural populations, thus decreasing migration to urban areas.

(3) Export of completed biological geotextiles to industrialised countries would earn hard currency for developing economies and promote development, based on the principles of fair trade.

(4) Biological geotextiles efficiently and economically conserve soil and would be especially beneficial for complex engineering problems. Temporary application of biogeotextiles would allow sufficient time for plant communities to stabilise engineered slopes.

The Project consisted of 13 work-packages using a team based in Europe (Belgium, Hungary, Lithuania and the UK), Africa (The Gambia and South Africa), South East Asia (China, Thailand and Vietnam) and South America (Brazil) (Fullen et al., 2007). The Project work-packages were organised along the three themes of 'experimental field studies', 'laboratory studies and modelling' and 'socioeconomic impacts and issues'. This paper reviews the project insights into the potential contribution of biogeotextile technology to soil conservation and sustainable development. 


\section{DISCUSSION}

Five papers are presented in this Special Issue:

1. Introduction and global perspectives (M. A. Fullen et al.).

2. Engineering properties and mat decomposition (R. W. Sarsby and R. Kugan).

This paper considers the geotechnical properties of biological geotextiles and their potential use in engineering applications. The temporal integrity of these materials is crucial in these applications and so attention is focused on decomposition rates.

3. Soil moisture conservation (A. Kertesz et al.).

Experiments in several continents and countries showed strong interactions between biogeotextile mats and both soil moisture and soil temperature. The mats generally impeded evaporation and were thus effective in retaining soil moisture, usually with beneficial effects on crop growth.

4. Runoff and erosion: laboratory versus field results (T. Smets et al.).

Comprehensive data sets are collated to discern general patterns in the interaction of biogeotextiles and runoff and erosion rates and patterns. This paper focuses on laboratory simulations and compares data with field results.

5. Runoff and erosion rates in the field (R. Bhattacharyya et al.).

Datasets are collated from several countries to distil general patterns in the interaction of biological geotextiles and runoff and erosion rates and patterns. As in paper (4), generally the biogeotextiles significantly $(p<0.05)$ decreased erosion rates, but runoff data are more ambivalent, with the materials sometimes increasing or decreasing runoff rates.

Project results were generally very positive; with direct field and laboratory evidence indicating biogeotextiles can have several beneficial effects, which were repeated in Africa, Europe, South America and South East Asia. Effects also appear consistent between selected land use systems (arable land, degraded gullied land and orchards). These are summarised in Table I. Consistent effects include:

1. The biological geotextiles were effective in reducing splash erosion, runoff and soil erosion on arable sloping land in Shropshire, UK (Bhattacharyya et al., 2009).

2. Results from selected types of vineyards in Hungary suggest that biogeotextiles were effective in reducing soil erosion, particularly during intense erosive rains. The biogeotextiles are also helpful in maintaining moisture and temperature conditions in the surface soil at levels particularly conducive to the establishment and growth of young plants. Biogeotextiles were effective in encouraging the establishment and growth of natural vegetation, thereby reducing erosion on roadside slopes in Lithuania.

3. Simulated experiments in controlled conditions in Belgium suggest that biogeotextiles are effective in increasing infiltration rates and reducing interrill runoff and erosion rates on medium (i.e. 15 per cent) and steep (i.e. 45 per cent) slope gradients (Smets et al., 2007).

4. Experiments on the effectiveness of biogeotextiles when used as geotechnical materials for the construction industry in ground strengthening showed that generally the tensile strength of the Buriti (constructed from leaf fibres of Mauritia flexuosa L.) mats was approximately twice that of the Borassus (constructed from leaves of Borassus

Table I. Environmental and societal effects of using biological geotextiles

Environmental Effects:

Decrease soil erosion rates (sediment yield and splash erosion)

Decrease runoff rates (complex effects?)

Increase soil moisture content

Buffer soil temperature changes

Prolong the autumn growing season (maintenance of higher soil temperatures for longer)

Encourage plant growth

Contribute nutrients to the soil system (?)

Contribute organic matter to the soil system (?)

Stabilise and protect vulnerable surfaces (e.g. archaeological sites)

Encourage soil faunal activity (i.e. earthworms)

Decrease plant diseases (i.e. fungal infection from humid air)

Societal Effects:

Some potential for domestic development (employment)

Encourage SME development

Export potential (?)

Biomedical potential (?)

Contribute to general environmental education and awareness

Contribute to agricultural extension

Note: ? denotes preliminary evidence, with long-term experiments and research in progress for verification 


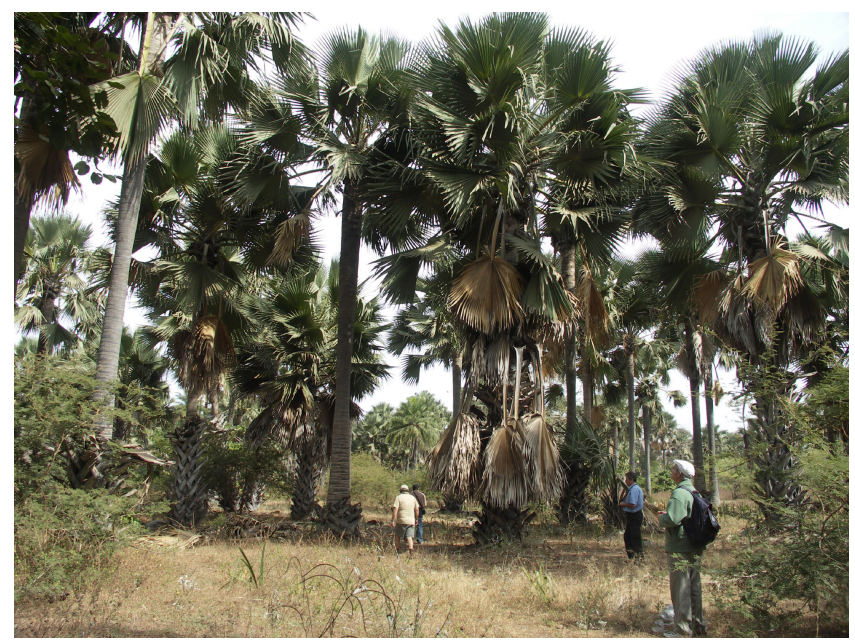

Plate I. Borassus (Borassus aethiopum L.) palm trees in The Gambia (January 2009). This figure is available in colour online at wileyonlinelibrary. com/journal/ldr.

aethiopum L.) mats (Plate I). The tensile strength of the biogeotextiles is influenced by the mat strip formation pattern.

5. Research and development activities of the Project have improved our knowledge on the effect of biological geotextiles on the micro- and macro-soil environments and at larger scales through controlled laboratory and field experiments in diverse environments.

6. Employing biological geotextiles significantly decreased water erosion rates, which accord with results from laboratory simulations of erosion processes (in Belgium, China and South Africa).

7. Biological geotextiles assist the conservation of soil water and decrease evaporation from soil during dry periods. As biogeotextile mats degrade, they may add organic matter to soil systems. However, longer term experiments are necessary to show any impact of using biogeotextiles on soil organic matter (SOM) improvement by offsetting some SOM losses by soil erosion and/ or oxidation. After 2 years, studies revealed that Borassus completely covered plots did not significantly $(p<0.05)$ increase SOM content in Shropshire, UK. Furthermore, geochemical analyses show both Borassus and Buriti fibres contain nutrients, which may be incorporated into soil systems as fibres degrade. Identified nutrients include magnesium $(\mathrm{Mg})$, phosphorus $(\mathrm{P})$, potassium $(\mathrm{K})$, calcium $(\mathrm{Ca})$, manganese $(\mathrm{Mn})$ and iron $(\mathrm{Fe})$. However, any significant effect of using biogeotextiles in improving these nutrients in soils would depend upon offsetting nutrient losses rather than their additions through the used mats.

The use of biological geotextiles has cost and resource implications. These include the costs of the production and
Table II. Estimated cost of biological geotextile production

\begin{tabular}{lc}
\hline Geotextile & Price $\left(€ \mathrm{~m}^{-2}\right)$ \\
\hline Synthetic & $0 \cdot 83-2 \cdot 75$ \\
Straw & $0 \cdot 45-0 \cdot 92$ \\
Jute & $0 \cdot 25-0 \cdot 83$ \\
Coir & $0 \cdot 75-1 \cdot 83$ \\
Geotextiles produced by the BORASSUS Project & \\
$\quad$ Borassus & $0 \cdot 35-0 \cdot 60$ \\
Buriti & $3 \cdot 20$ \\
Bamboo & $0 \cdot 48$ \\
Maize stalks & 4.40 \\
Rice straw & 1.45 \\
\hline
\end{tabular}

Sources: Smith (2001), Smets (2009).

distribution of mats and labour costs in their emplacement. Generally, Borassus mats can be constructed at a competitive price of $\sim € 0.5 \mathrm{~m}^{2}$, which is in the mid-price range compared with other biogeotextiles (such as jute and coir geotextiles) (Table II). Smets (2009) reviewed the costs of biogeotextiles, based on a literature review and data collated by the BORASSUS Project (Table II).

On this comparative basis, Borassus and bamboo mats are in the mid-price range. Rice straw mats are in the upper mid-price range and Buriti and maize stalk mats are relatively expensive. However, in some cases, for instance on archaeological sites, Buriti mats were more time-efficient to manage (emplace and remove) than the alternative jute mats. There are also complications due to government policies. For instance, government minimum wage levels in South Africa meant Lala palm mats cost $\sim € 3.5 \mathrm{~m}^{2}$, some six times the cost of imported jute mats. However, this must be balanced against the high rate of rural unemployment in South Africa, and if a subsidy instrument could be established as an integral component of a job creation scheme, there would be the double benefit of local empowerment and soil erosion control. Moreover, all cost estimates within the BORASSUS Project are based on small-scale cottage industry production. If production was organised on larger scales, unit costs would fall considerably.

While widespread use of biological geotextiles is probably not economically viable, Project results suggest that they are particularly appropriate in high-value and complex applications. Studies show these sites could include orchards, vineyards, archaeological sites, agroforestry sites, building and road construction sites, urban erosion sites, gully stabilisation and reclamation projects, coastal defence and mine tailings. Results suggest that use of biogeotextiles (Borassus mats) as buffer strips at the lower end of plots (area coverage $\sim 10$ per cent) was as effective as complete cover of the same mats on loamy sand soils in the UK. Thus, buffer strips of mats could be targeted on steep and/or 
erodible agricultural soils and, thus, diminish overall soil loss from eroding landscapes.

The BORASSUS Project added knowledge on five specific themes.

\section{Innovative Soil Conservation Technology}

Field erosion plot studies have been completed at 13 sites in Africa, Asia, Europe and South America. Results suggest biological geotextiles are very effective in terms of significantly decreasing water erosion rates. Field results are supported by laboratory simulation data. These laboratory experiments suggest biogeotextiles are very effective in reducing total inter-rill soil loss, especially on gentler slopes, but are less effective in reducing runoff volumes (Smets et al., 2007). On steeper slopes their effectiveness decreased. The simulated biogeotextiles with the smallest mesh sizes $\left(1 \times 1 \mathrm{~cm}^{2} ; \sim 84\right.$ per cent cover $)$ were the most effective in reducing erosion rates and runoff volumes on three slopes $(15,30$ and 45 per cent). Thus, the Project team is carefully developing protocols, where the studied biogeotextiles could be targeted for very specific bioengineering applications.

Soil bioengineering techniques have been applied in Sacavém gully (São Luís, North-East Brazil) using biological geotextiles constructed from Buriti palm trees (Plate II). The aim is to minimise soil erosion, by intercepting rainfall, retarding runoff velocity and sediment loss. These techniques included: (i) using Buriti geotextiles in association with barriers of wooden stakes and the construction of contoured terraces. (ii) analysis of sediment particle size; and (iii) photo comparison of the development of vegetation cover.

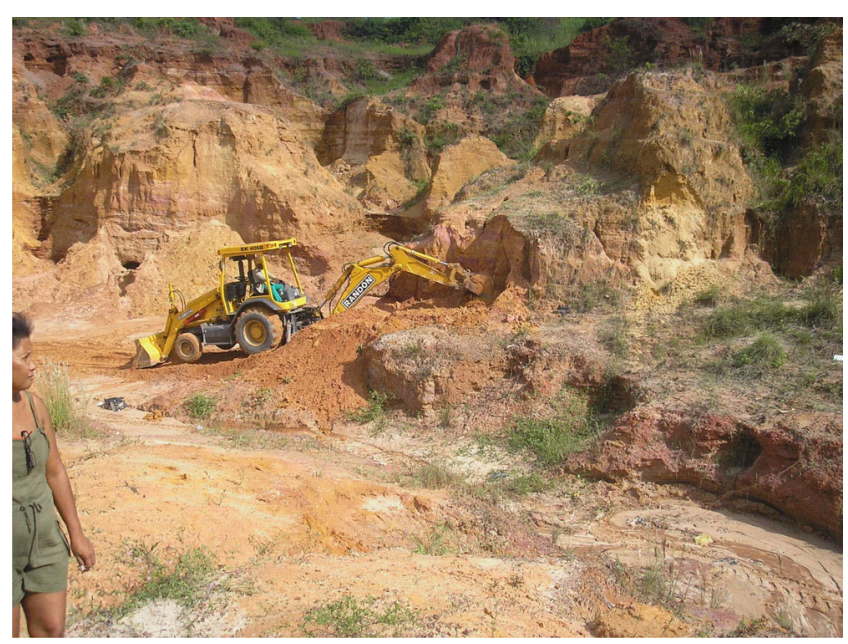

Plate II. Initial landscaping work in Sacavém gully, São Luís, Brazil (February 2008). This figure is available in colour online at wileyonlinelibrary. com/journal/ldr.
Due to difficulties in diverting flows, which would require more extensive engineering works, the gully channel was maintained, and the basal slope was strengthened to support the flows. In the upper part of this area (slope angle $\sim 8$ degrees), contours were surveyed and barriers of wooden stakes were used to decrease runoff velocity from adjacent vegetated slopes. Some slope segments had slope angles of $\sim 45$ degrees. However, this was considered too steep for the effective application of biological geotextiles.

Complete vegetation cover developed in only 1 month. However, only 1 month after the rehabilitation work was completed, the area was exposed to intense erosive rains (1month total (10 March 2008-09 April 2008) 753.7 mm, with a recurrence interval of $\sim 60$ years). Vegetation resisted erosion and the Buriti geotextiles achieved the main objective of arresting erosion and rehabilitating the gullied area (Plate III). Only minor rehabilitation work was needed after these storms. However, this does emphasize that success requires continued high-quality maintenance, which is being achieved by local people, under project supervision. Textural data show that the main component material of the slopes at Sacavém gully is sand, with most samples being $>90$ per cent sand. Thus, the soils are highly erodible and so the use of biological geotextiles is proving very effective in arresting erosion processes. On going site-development can be viewed on the e-photo album of the 'Laboratory of Environmental Geomorphology and Land Degradation of the Federal University of Rio de Janeiro' (LAGESOLOS) at: http://www.lagesolos.ufrj.br.

To complement studies at Sacavém gully, an experimental station was established on the nearby $(\sim 5 \mathrm{~km}$ distant $)$ Campus of Maranhão Federal University on Regolithic Neosols. Rainfall, runoff, sediment loss, soil matric potential

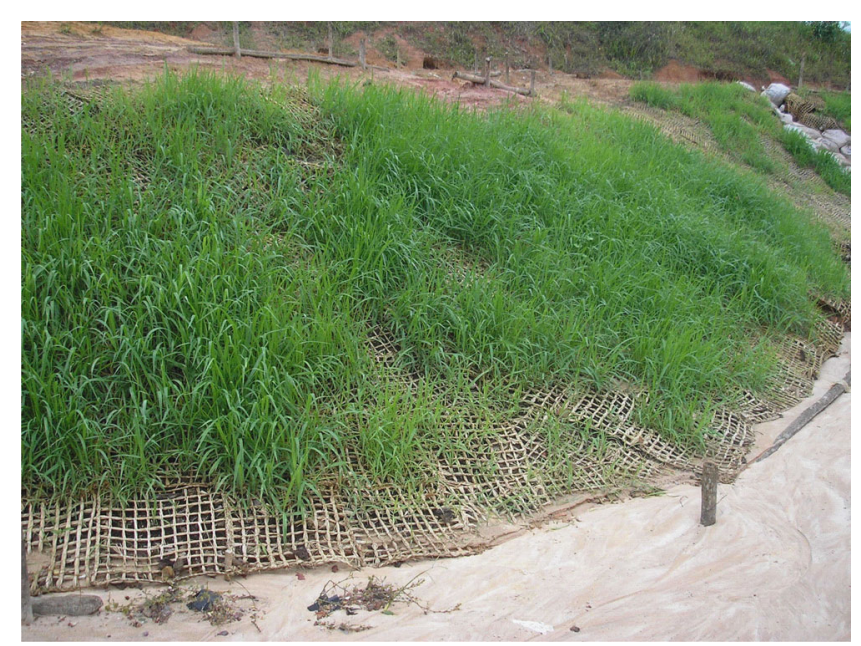

Plate III. Grass development within Sacavém gully, 1-month after rehabilitation (April 2008). This figure is available in colour online at wileyonlinelibrary.com/journal/ldr. 
and vegetation cover index (VCI) were measured on bare and vegetated (geotextiles plus grass) plots over the 2009 rainy season (2 February-30 June 2009). Two replicate plots $\left(1 \times 10 \mathrm{~m}^{2}\right)$, on a $20^{\circ}$ slope were established, with two treatments: (i) Bare soil and (ii) Buriti geotextiles with grass cover. At the bottom of each plot, a Gerlach trough was connected to a $200 \mathrm{~L}$ capacity tank, to collect runoff and sediment. The bare soil was maintained by regularly removing weeds and grass by hand. On the Buriti plots, NPK was added, grass seeds (Brachiaria decumbens $)$ were applied and $40\left(0.50 \times 0.50 \mathrm{~m}^{2}\right)$ geotextiles emplaced.

During the rainy season (2 February-30 June 2009) total precipitation was $2067.6 \mathrm{~mm}$ (mean monthly rainfall $413.5 \mathrm{~mm})$. April had the highest total rainfall $(650.0 \mathrm{~mm})$ and June least $(166.7 \mathrm{~mm})$. Soil matric potential was measured at different depths in the soil profile (10, 20, 40 and $60 \mathrm{~cm}$ ). These data allowed identification of the extent and periodicity of saturated and unsaturated zones.

Soil matric potential data suggest the geotextile plots experienced better water circulation in the soil profile than the bare plots. At $10 \mathrm{~cm}$ depth, the mean matric potential of geotextiles and bare plots varied from -4.8 to $-5.7 \mathrm{kPa}$ and -2.2 to $-4.5 \mathrm{kPa}$, respectively. At $20 \mathrm{~cm}$ depth, the mean negative suction ranged from -5.7 to $-11.5 \mathrm{kPa}$ (geotextiles with grass cover plot) and -6.0 to $-7.2 \mathrm{kPa}$ (bare plot). At $40 \mathrm{~cm}$ depth, mean values varied from -4.7 to $-12.8 \mathrm{kPa}$ in the geotextile plots and -4.5 to $-3.1 \mathrm{kPa}$ in the bare plots. At $60 \mathrm{~cm}$ depth, the mean values for geotextile and bare plots were $(-1.2,-29.6)$ and $(-10.6,-14.5 \mathrm{kPa})$, respectively.

There were major differences in terms of runoff and erosion rates between the bare and geotextile plots. For instance, the $2067.6 \mathrm{~mm}$ of rainfall caused $4068 \mathrm{~L}$ of runoff from the geotextile plots. Comparative runoff from the bare plots was more than double, at $9893 \mathrm{~L}$. Total sediment loss on the bare plots was $87819 \mathrm{~g}$, compared with $5117 \mathrm{~g}$ on the geotextile plots. Comparative analysis with the erosion pin data shows the erosional behaviour of the two bare soil plots to be very similar. Only six of the 32 pins experienced soil accumulation, whereas on 26 pins there was surface lowering, which ranged between 5.10 and $6.47 \mathrm{~cm}$. Studies are ongoing at both the Sacavém and Maranhão University Campus sites and will be reported in subsequent papers.

Field evidence suggests the use of biogeotextiles may be particularly valuable on archaeological sites. The Isle of Man (British Isles) possesses some of the richest and most diverse archaeological heritages in Europe, including Neolithic, pre-Christian Celtic, Norse and Medieval sites. Experiments were conducted at the Medieval site of Rushen Abbey, which was established by Cistercian monks in AD 1154 (Plate IV). To protect the site after summer

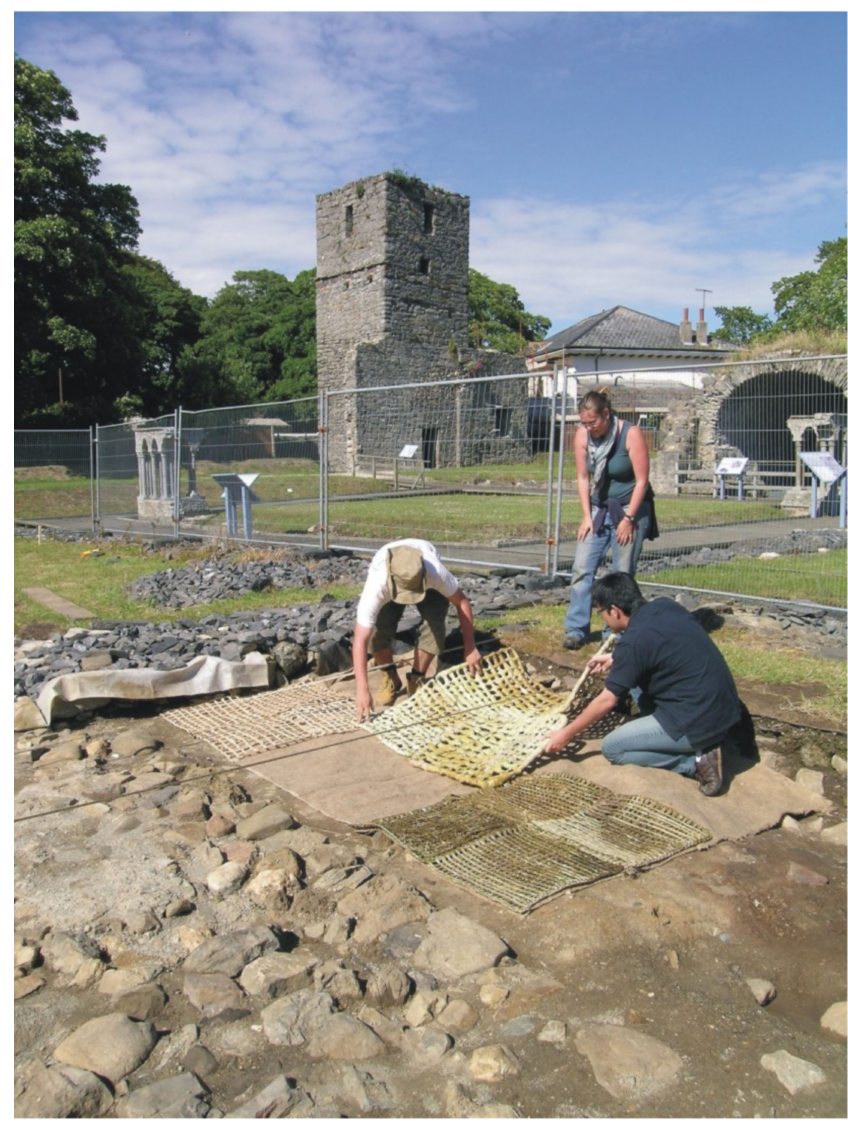

Plate IV. University of Liverpool archaeology students laying mats for an educational display, Rushen Abbey, Isle of Man (June 2008). This figure is available in colour online at wileyonlinelibrary.com/journal/ldr.

excavations, geotextiles were laid in August 2007 and removed on 9 June 2008. Buriti mats performed particularly well and impeded both floral and faunal disturbance of the archaeological material (Plate V).

\section{Innovative Crop Support Technology}

Experiments on the effects of biological geotextiles on seedling establishment on road cuttings in Lithuania reveal that shoot density of perennial grasses on the plots covered by geotextile mats were significantly higher (factor $6 \cdot 3-9 \cdot 1$ times higher) than the control (uncovered) plots. Investigations suggest these benefits are related to physicochemical interactions between mats and their environment. Field experiments in Europe and tropics/subtropics are remarkably mutually supportive, suggesting improved topsoil water economy. This extends to increased soil moisture retention and decreased evaporation from soil systems during dry periods. Moreover, the mats contain and retain nutrients, which would promote rapid vegetation establishment. Geochemical analyses show that palm-mat 


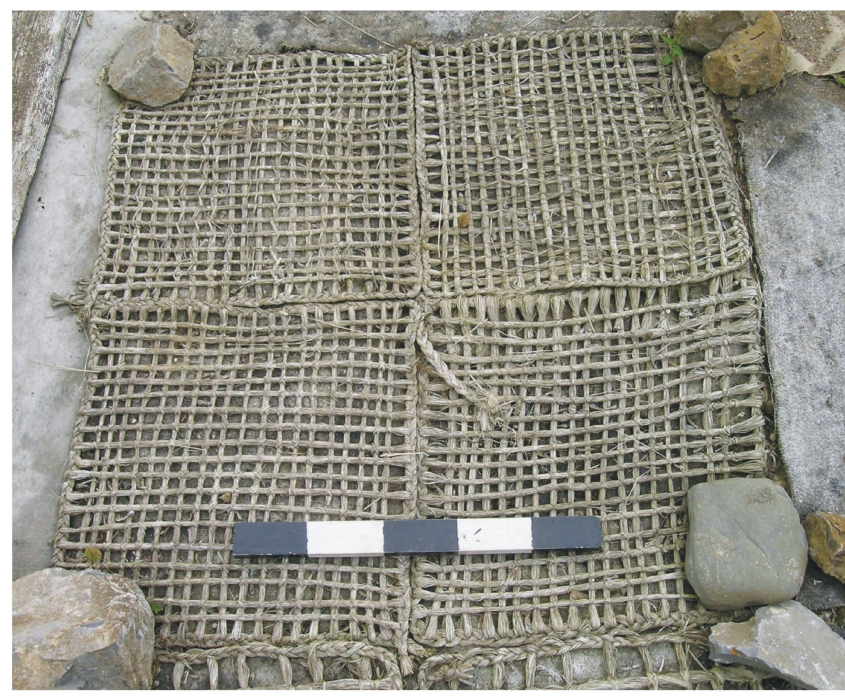

Plate V. Well preserved close-weave Buriti geotextiles after 10 months field emplacement, Rushen Abbey, Isle of Man (June 2008). This figure is available in colour online at wileyonlinelibrary.com/journal/ldr.

biogeotextiles have considerably higher $\mathrm{K}, \mathrm{Mg}, \mathrm{P}$ and nitrogen $(\mathrm{N})$ contents than jute-mats. Data from South-East Asia show these effects can stimulate significant $(p<0.05)$ improvements in crop yield, while simultaneously conserving soil, water and nutrients within agro-environmental systems. These beneficial effects appear general and have been identified in several studied crops, including maize, soybeans (Glycine max L.), lablab bean (Lablab purpureus L.), chickpea (Cicer arietinum L.), peanuts (Arachis hypogoea L.) and winter wheat (Triticum aestivum L.). In Vietnam it was noted that improved air circulation around the 'checkerboard' structure of crops growing through biomats diminished plant diseases during wet periods. The observed physico-chemical interactions between biomats and soil systems suggest that these biogeotextiles could be used to effectively, efficiently and rapidly promote vegetation establishment in land reclamation projects. This offers potential benefits in terms of protecting land from soil erosion and there appears to be many exciting opportunities in terms of land reclamation projects.

\section{Innovative Eco-engineering Technology}

Many of the developing world's leading engineers have been trained in western universities, where they are taught about western products and how to use western engineering manuals to solve various engineering issues. However, it is important that, if appropriate to the interests of a sustainable construction industry, indigenous engineering products manufactured from local materials are evaluated and promoted as alternative products. Moreover, it is paramount that developing world engineers are re-educated and informed about indigenous products, which, when implemented, will be beneficial to the socio-economic development of these countries. Studies during the last three-plus years suggest biological geotextiles are particularly applicable and effective in specific, complex and problematic areas (e.g. agro-forestry systems, alley cropping systems, archaeological sites, embankments, fruit orchards, mining sites, reclaimed sites, road cuttings, vineyards and wax-tree orchards).

\section{Socio-Economic Development}

To be a viable solution to agro-environmental problems, the use of biological geotextiles must be feasible from a socioeconomic perspective. Cost-benefit analyses suggest costs are usually realistic in terms of both domestic and international trade. Initial discussions are in progress on product development with small and medium enterprises (SMEs). The BORASSUS team believe these products could form a vital and integrated component of socio-economic development projects. For example, Buriti products are being used in Brazil for wood (producing moderate value wooden products, such as small boxes), fruit (producing edible fruit, fruit juices and ice cream for domestic retail) and palm-fibres. The high-quality fibres are used to produce high-value products (such as hats, bags and household mats). The remaining low-grade relatively coarse fibres are used for the construction of biogeotextiles. Previously, these products were treated as excess waste. This recycling aspect contributes to the economic-viability of the product. Furthermore, Buriti oil may have biomedical applications, as a rich source of beta-carotene and vitamin A and may protect against skin cancer (Santos, 2005). Used Buriti fibres can then be burnt, to provide an ash-based fertilizer, or the fibres may be composted. Thus, the integrated system has virtually no waste materials. The costs of reclamation work in Sacavém gully were carefully audited and totalled $\mathrm{R} \$ 15,780$ (€6,069; €1.00= R $\$$ (Brazilian Reais) 2.60 in March 2008). Ongoing cost/benefit analysis is assessing the time-horizon to project profitability from the sale of products grown in the reclaimed gully. The BORASSUS team envisage the production of biogeotextiles would be embedded within such larger integrated socio-economic packages.

Different approaches were used by different partners for the implementation of Project activities, mat production and awareness creation. The approaches varied from the use of hired labour to collaboration with local communities and local government and the involvement of local youths. The approaches used affected degree of success in achieving the expected socio-economic and sustainability outcome. For example, Vietnamese partners collaborated with the local government authority; as a result Project outcomes were adopted by the local authority for further dissemination. 
Out of the 12 partner institutions that collaborated in the Project, six partners (South Africa, Brazil, China, Thailand, Vietnam and The Gambia) were involved in the production of biological geotextiles. Most partners produced the biogeotextiles required for their research and development purposes. The Gambia and Brazil produced biogeotextiles on a more commercial scale. The Gambia produced Borassus mats and Brazil produced Buriti mats in sufficient quantities required by all partners (both domestic and European) for their research and development activities. There were variations in the material used for making mats, but mat sizes were similar, as $0.25 \mathrm{~m}^{2}\left(0.5 \times 0.5 \mathrm{~m}^{2}\right)$ size was convenient to produce, transport and use in the field.

There were considerable variations in production costs, which ranged from $€ 1.0 \mathrm{~m}^{-2}$ in China to $€ 3.5 \mathrm{~m}^{-2}$ in South Africa. The differences in production costs are mainly attributed to differences in wage rates and modes of production. Labour was hired in South Africa; this means weaving mats was the main job and hence formed the main source of family income for the employed labourers. In Vietnam, China and The Gambia, mats were prepared by community members in their spare time, where mat weaving was often performed by elderly and disabled people, who found other work difficult. Thus, the Project was not financially viable in South Africa, as it was seven times more expensive than the imported alternative of jute geotextiles. In contrast, partners in China, Vietnam and The Gambia reported successes in making mat production a profitable cottage industry.

Different approaches were adopted by partners to create awareness. In Vietnam, regular meetings/discussions, periodic training courses and field visit were organised between the Tamnong District Authority, farmers and the Project team in order to achieve effective collaboration. During field visits, the District Authority appreciated the contribution of the BORASSUS Project for developing biogeotextile production techniques using different types of plant material; increasing household income through biogeotextile production; and developing biogeotextile technology effective for soil erosion control, soil moisture conservation, weed control and increased crop productivity. This indicates that collaborative action enhanced the realisation of benefits from project technologies among local stakeholders.

The Project in The Gambia worked with womens' groups. After a series of discussion and training sessions, local communities (particularly women and the elderly) in The Gambia are now aware of the effects of deforestation, benefits of reforestation and potential of sustainable use of the palm for income generation. Consequently, local communities have embarked on tree nursery projects for the development of large palm plantations.
The project team in Brazil promoted 'land literacy' for the future citizens (i.e. participation of school children and young people from impoverished communities). The environmental education and awareness activity of the Project addressed issues surrounding unauthorised urban settlement expansion and their concomitant effects, which have promoted acute land degradation and initiated severe gully formation. The work embraced general knowledge through to the specific, always associating with pre-existing individual knowledge, which enhanced the personal development of students. This personal development embraced technical training, behavioural changes, improvements in self-esteem and self-belief, plus the development of a teamwork ethos. For instance, local youths vandalised the initial pilot study plots and destroyed them by fire. Since then, these same youths have enrolled in the Environmental Education Programme and no subsequent destruction has occurred. Other behavioural changes included improved concern for the environment, attention to wildlife welfare, decreased discarding of litter and overall better educational performance. Their participation intrigued other family members to attend Project events and discussions, which widened community participation in the remediation of degraded areas. Furthermore, these approaches forged greater educator-student interaction and encouraged local community groups to establish an environmental partnership. This axis of environmental education brings with it a wider vision that involves not only the natural, but the also social and built aspects associated with environmental issues. Educators and instructors also learnt about the aims and aspirations of the Sacavém Community. It is anticipated this programme will act as a generic model for such community-involvement activities in South America and beyond.

Awareness programmes for local youths in Brazil resulted in increased community participation in Project activities. Involvement of local communities in The Gambia reversed the trend of deforestation and triggered community initiatives for the establishment of community forestry. Thus, collaborative partnerships with local community and local government helped post-project continuation of Project work in The Gambia, Vietnam and Brazil. Environmental conservation and socio-economic development issues are multi-faceted, where different actors are involved in diverse ways; therefore success in environmental conservation programmes depends on the efforts of these stakeholders, primarily local communities (Subedi et al., 2009a). In addition, when local community members play effective roles in awareness creation; they can act as extension workers themselves, as they can relate more readily to their fellow farmers and thus act as facilitators of technology transfer. This concept of 'farmer-to-farmer dissemination' has proved very effective (Maglinao, 1996; 
Garforth et al., 2003; Subedi et al., 2009b). The Project partner in Brazil encountered a similar situation, where efforts to create awareness among local youths engendered increased interest in the local community and participation in Project activities. Once local youths were aware about environmental issues after participating in the Project's environmental education programme, they became instrumental in sensitising other community members.

BORASSUS Project activities in Vietnam were implemented in collaboration with local government authorities and farmers' groups. Farmers were involved in project implementation and their advice was integral to the decision-making process. Farmers were involved in all stages of the Project (implementation, monitoring, field visits and discussions). In an attempt to study farmers' perceptions about the effectiveness of different types of biogeotextile, farmers were requested to rank them against some important indicators. Farmers' overall preference was for maize mats. Compared to maize mats, farmers found bamboo mats more effective in conserving soil moisture and durability. Similarly, farmers regarded Borassus mats as more effective for soil protection, durability and soil moisture conservation than maize mats. Despite this, farmers' overall preference for maize mats seemed to be due to its availability, cost-effectiveness and ease of construction, which indicate that these are the most important indicators for farmers' acceptance and adoption.

Despite the technical suitability of these biogeotextiles in reducing water erosion, their future adoption, however, will be influenced both by production costs and prices. Unless the proposed biogeotextiles are cheaper than available alternatives on the market (for example jute and coir), users would not accept or adopt the more expensive option. Production costs are dictated mainly by wage, material and transport costs. For example, the biogeotextiles produced in South Africa were more expensive because of higher wage rates. The biogeotextiles produced by the Project were consequently more expensive that other available options in the market and thus the Project did not appear to be economically viable in South Africa. Households producing biogeotextiles in China enjoyed the income from their production, because wage rates were considerably lower than in South Africa.

Biological geotextiles were produced using full-time hired labourers in South Africa, which meant biogeotextile production was their primary occupation. In contrast, in The Gambia, China and Vietnam, biogeotextile production was an additional job. Community members produced biogeotextiles whenever they were free from their main occupation. Any earning from biogeotextile production was an additional-income for them, while for South African workers the income from production was their main income. Thus, community members in The Gambia, China and
Vietnam who were involved in producing biogeotextiles enjoyed comparatively better earnings than South African labourers.

To be an economically viable industry, biogeotextile production has to compete with other materials on the market, for example jute and coir, which are produced using the efficiency of modern industrial advances. It is difficult for hand-made biogeotextiles to compete with these industrial products, due to differential production costs. Therefore a cottage-scale industry as a secondary parttime occupation seems to be a suitable and potentially economically viable mode of production.

\section{Encouragement to the Development of Niche-Based Technologies}

Initially, the Project aimed to test biological geotextiles made of Borassus palm-leaves, which is indigenous to North Africa. During project development, team members were intrigued by the concept of making such biogeotextiles from the by-products of locally available natural resources and using them for soil and water conservation. This encouraged them to make biological geotextiles which are abundant, easily accessible and cheap in their area. Thus, in addition to Borassus mats, Buriti palm mats (Brazil), Lala palm (Hyphaene coriacea L.) mats (South Africa), rice straw mats (China), bamboo mats (Thailand), maize stalk mats (Vietnam) and mats constructed from Imperata grass (Imperata cylindrica L.) (Thailand) were tested for their effectiveness in controlling water erosion. Hence, the Project efforts prompted the development of several technologies suited to different agro-environmental and socio-economic niches.

Further information can be obtained from the BORASSUS Project website (www.borassus-project.net). Full Project publications can be accessed on the University of Wolverhampton WIRE free-access web site: http://wlv.openrepository.com/wlv/.

\section{CONCLUSIONS}

The use of biological geotextiles constructed from indigenous leaves, leaf fibres or stems has potential as a soil conservation method. Investigations used palm-leaves, but these broadened to include other indigenous leaves or stems (i.e. bamboo, Imperata grass, maize, rice and wheat). Thus, developing technologies are flexible and can be adapted to local conditions. Experiments showed that biological geotextiles constructed from indigenous bioresources effectively decreased soil erosion. They were found effective in reducing soil and water losses in varied land use types (arable land, orchards and engineered roadside slopes). They contributed favourably to the growth of both crops and natural vegetation. If harvested correctly, 
these resources are sustainable and readily available in many bioclimatic regions. They are biodegradable, providing organic matter and nutrients to the soil and their permeability makes them suitable for use with cohesive soils. There are no high-energy production procedures in the manufacturing process and they may provide a costeffective method of conserving soil in developing countries, where farming techniques are scaled to low levels of disposable income. They are also applicable in soil and water conservation projects in European environments. Thus, while soil conservation is largely an environmental engineering problem, we need to recognise that effective conservation has social, economic, educational and political dimensions. The BORASSUS team strongly argue for an integrated environmental and socio-economic approach to soil conservation.

\section{ACKNOWLEDGEMENTS}

This work is dedicated to the memory of Dr. Kathy Davies, who initiated and inspired the concept of developing palmleaf biological geotextiles. We also gratefully thank all technical and support staff involved with this Project. All authors acknowledge and thank the European Commission for the financial support of the BORASSUS Project (contract number INCO-CT-2005-510745) and Dr. Michele Genovese (of the European Commission) for his advice and support.

\section{REFERENCES}

Bhattacharyya R, Fullen MA, Davies K, Booth CA. 2009. Utilizing palm leaf geotextile mats to conserve loamy sand soil in the United Kingdom. Agriculture, Ecosystems and Environment 130: 50-58.

Booth CA, Davies K, Fullen MA. 2005. Environmental and socio-economic contributions of palm-leaf geotextiles to sustainable development and soil conservation. In Ecosystems and Sustainable Development V, Tiezzi E, Brebbia CA, Jorgensen SE, Almorza Gomar D (eds). WIT Press: Southampton (UK); 649-658.

Booth CA, Fullen MA, Sarsby RW, Davies K, Kugan R, Bhattacharyya R, Poesen J, Smets T, Kertesz A, Toth A, Szalai Z, Jakab G, Kozma K, Jankauskas B, Trimirka V, Jankauskiene G, Bühmann C, Paterson G, Mulibana E, Nell JP, van der Merwe GME, Guerra AJT, Mendonça JKS, Guerra TT, Sathler R, Zheng Yi, Yongmei Li, Panomtarachichigul M, Peukrai S, Thu DC, Cuong TH, Toan TT, Jonsyn-Ellis F, Jallow S, Cole
A, Mulholland B, Dearlove M, Corkill C. 2007. The BORASSUS Project: Aims, objectives and preliminary insights into the environmental and socio-economic contribution of biogeotextiles to sustainable development and soil conservation. In Sustainable Development and Planning III, Kungolas A, Brebbia CA, Beriatos E (eds). WIT Press: Southampton (UK); 601-610.

Davies K, Fullen MA, Booth CA. 2006. A pilot project on the potential contribution of palm-mat geotextiles to soil conservation. Earth Surface Processes \& Landforms 31: 561-569.

Fullen MA, Booth CA, Sarsby RW, Davies K, Kugan R, Bhattacharyya R, Subedi M, Luckhurst DA, Poesen J, Smets T, Kertesz A, Toth A, Szalai Z, Jakab G, Kozma K, Jankauskas B, Jankauskiene G, Bühmann C, Paterson G, Mulibana E, Nell JP, van der Merwe GME, Guerra AJT, Mendonça JKS, Guerra TT, Sathler R, Bezerra JFR, Peres SM, Zheng Yi, Li Yongmei, Tang Li, Panomtaranichagul M, Peukrai S, Thu DC, Cuong TH, Toan TT, Jonsyn-Ellis F, Jallow S, Cole A, Mulholland B, Dearlove M, Corkill C. 2007. The contribution of biogeotextiles to sustainable development and soil conservation in developing countries: The BORASSUS Project. In Sustainable Development VI, Tiezzi E, Marques JC, Brebbia CA, Jørgensen SE (eds). Wessex Institute of Technology Press: Southampton, UK; 123-141.

Garforth C, Angell B, Archer J, Green K. 2003. Fragmentation or creative diversity? Options in the provision of land management advisory services. Land Use Policy 20: 323-333.

Jankauskas B, Jankauskiene G, Fullen MA. 2010. The protection of sand dunes on the Baltic coast using palm-mat geotextiles. Tiltai (Bridges), The Journal of Klaipeda University 1: 119-127.

Maglinao AR. 1996. Accelerating technology transfer and adoption: The challenge to research and extension. In Soil Conservation Extension: From Concepts to Adoption, Sombatpanit S, Zobisch MA, Sanders DW, Cook MG (eds). Science Publishers Inc.: Enfield, NH.

Rickson RJ. 2000. The use of geotextiles for vegetation management. Aspects of Applied Biology 58: 107-114.

Santos LMP. 2005. Nutritional and ecological aspects of buriti or aguaje (Mauritia flexuosa Linnaeus filius): A carotene-rich palm fruit from Latin America. Ecology of Food \& Nutrition 44: 345-358.

Smets T. 2009. Effectiveness of biological geotextiles at controlling soil erosion by water at a range of scales, Ph.D. thesis, University of Leuven: Leuven, Belgium; 287.

Smets T, Poesen J, Fullen MA, Booth CA. 2007. Effectiveness of palm and simulated geotextiles in reducing run-off and inter-rill erosion on medium and steep slopes. Soil Use and Management 23: 306-316.

Smith R. 2001. The potential market for sisal and henequen geotextiles. In: Food and Agriculture Organization and Common Fund for Commodities. Proceedings of Seminar, Rome, Technical Paper 14.

Subedi M, Hocking TJ, Fullen MA, McCrea AR, Milne E, Wu B, Mitchell DJ. 2009a. Use of farmers' indicators to evaluate the sustainability of modified cropping practices and environmental measures on sloping land: A case study in Yunnan Province, China. Pedosphere 19: 344-355.

Subedi M, Hocking TJ, Fullen MA, McCrea AR, Milne E, Wu B, Mitchell DJ. 2009b. An evaluation of the introduction of modified cropping practices in Yunnan Province, China, using surveys of farmers' households. Agricultural Sciences in China 8: 188-202. 